\title{
AKTIVITAS ANTIBAKTERI DAN ANTIOKSIDAN HIDROLISAT HASIL HIDROLISIS PROTEIN SUSU KAMBING DENGAN EKSTRAK KASAR BROMELIN
}

\author{
[Antibacterial and Antioxidant Activity of Hydrolysate from Goat Milk Protein Hydrolized \\ by Crude Bromelain Extract]
}

\author{
Eni Kusumaningtyas ${ }^{1,2)}$, Raphaella Widiastuti ${ }^{1)}$, Harsi Dewantari Kusumaningrum²), \\ dan Maggy Thenawidjaja Suhartono ${ }^{2) \star}$ \\ 1) Balai Besar Penelitian Veteriner, JI RE Martadinata 30 Bogor, Bogor \\ 2) Departemen IImu dan Teknologi Pangan, Fakultas Teknologi Pertanian, Institut Pertanian Bogor, Bogor
}

Diterima 03 Agustus 2015 / Disetujui 02 November 2015

\begin{abstract}
Goat milk is highly nutritious foodstuffs that beneficial for improving health. The milk contains bioactive peptides which produced by hydrolysis process. The aim of this study was to evaluate antibacterial and antioxidant activities of hydrolisate produced from hydrolysis of goat milk protein by crude bromelain extract. Hydrolysis of goat milk protein was conducted using crude bromelain $(0.1 \mathrm{U} / \mathrm{mL})$ at $\mathrm{pH}$ $6,50^{\circ} \mathrm{C}$ for $60 \mathrm{~min}$. Hydrolysate was fractionated by using membrane molecular weight cut off $10 \mathrm{kDa}$. hydrolysate before and after fractionation were assayed for antib acterial and antioxidant activities. Toxicity of the Hydrolysate was determined by hemolysis assay. The result showed that the hydrolysate before and after fractionation inhibited growth of E. coli, S. Typhimurium and L. monocytogenes. Hydrolysate after fractionation has higher antibacterial activity indicated that fractionation was able to improve antibacterial activities of the hydrolysate fraction. The hydrolysate showed scavenging activity to ABTS and DPPH radicals. Fraction $<10 \mathrm{kDa}$ has the highest antioxidant activity against both ABTS and DPPH radicals. Hemolysis assay showed that hydrolysate before and after fractionation did not cause lysis of red blood cells, indicating safe for application. Both fraction $<10 \mathrm{kDa}$ and $>10 \mathrm{kDa}$ not only showed absence of hemolysis but also they were able to reduce autolysis of red blood cells. The result showed that hydrolysate from goat milk hydrolyzed by bromelain were able to be antibacterial and antioxidant.
\end{abstract}

Keywords: antibacterial, antioxidant, bromelain, goat milk, hydrolysate

\begin{abstract}
ABSTRAK
Susu kambing merupakan bahan pangan bernutrisi tinggi yang bermanfaat untuk meningkatkan kesehatan. Susu mengandung peptida bioaktif yang dapat dihasilkan melalui proses hidrolisis. Tujuan dari penelitian ini adalah untuk mengevaluasi aktivitas antibakteri dan antioksidan hidrolisat yang dihasilkan dari hidrolisis protein susu kambing dengan bromelin. Hidrolisis protein susu kambing dilakukan menggunakan eks trak kasar bromelin $(0,1 \mathrm{U} / \mathrm{mL})$ pada $\mathrm{pH} 6,50^{\circ} \mathrm{C}$ selama 60 menit. Hidrolisat difraksinasi menggunakan membran molecular weightcutoff $10 \mathrm{kDa}$. Hidrolis at sebelum dan sesudah fraksinasi diuji kemampuan antibakteri dan antioksidannya. Toksisitas hidrolisat dan hasil fraksinasinya ditentukan dengan uji hemolisis. Hasil menunjukkan bahwa hidrolisat sebelum dan sesudah fraksinasi dapat menghambat pertumbuhan E. coli, S. Typhimurium dan L. monocytogenes. Hidrolisat setelah fraksinasi mempunyai aktivitas antibakteri lebih tinggi yang mengindikasikan bahwa fraksinasi dapat meningkatkan aktivitas antibakteri. Fraksi hidrolisat juga menunjukkan aktivitas netralisasi radikal ABTS dan DPPH. Fraksi $<10$ kDa mempunyai aktivitas antioksidan yang paling tinggi terhadap radikal ABTS dan DPPH. Uji hemolisis menunjukkan bahwa hidrolisat sebelum dan sesudah fraksinasi tidak menimbulkan lis is pada sel darah merah menandakan aman untuk diaplikasikan. Kedua fraksi $<10 \mathrm{kDa}$ dan $>10 \mathrm{kDa}$ tidak hanya menunjukkan ketidakberadaan hemolis is tetapi juga dapat menurunkan autolis is pada sel darah merah. Hasil tersebut menunjukkan bahwa susu kambing yang dihidrolisis dengan bromelin dapat berfungsi sebagai antibakteri dan antioksidan.
\end{abstract}

Kata kunci: antibakteri, antioksidan, bromelin, hidrolisat, susu kambing

\section{PENDAHULUAN}

Susu merupakan bahan pangan bernutrisi tinggi yang ditandai dengan keseimbangan asam aminonya dan dapat meningkatkan kesehatan. Susu juga dapat menjadi sumber peptida bioaktif dengan fungsi biologis yang luas (Szwajkowska et al., 2011).

*Penulis Korespondensi:

E-mail: mthenawidjaja@yahoo.com 
Peptida bioaktif yang berasal dari protein susu sapi telah banyak dilaporkan, diantaranya adalah peptida yang dapat berfungsi sebagai antihipertensi (Mos-lehishad et al., 2013), antibakteri (Atanasova dan Ivanova 2010) antitrombotik, opioid, opioid antagonis, immunomodulator, antifungi, mencegah amnesia, dan optimalisasi kontrol kontraksi dan relaksasi otot polos (Szwajkowska et al., 2011) misalnya pada kandung kemih (Uckert et al., 2002).

Susu kambing telah lama dimanfaatkan sebagai pengganti susu sapi terutama yang mempunyai risiko alergi terhadap protein susu sapi. Meskipun demikian, laporan mengenai pemanfaatan susu kambing sebagai penghasil peptida bioaktif belum banyak dilaporkan. Beberapa peptida bioaktif hasil hidrolisis enzimatik susu kambing yang telah teridentifikasi adalah peptida antibakteri (Almaas et al., 2011), antioksidan ( $\mathrm{Li}$ et al., 2013) dan penghambat Angiotensin converting enzyme (ACE) (Nandhini et al., 2012). Peptida-peptida tersebut biasanya masih terikat dalam protein alamiahnya dan dapat diisolasi melalui proses hidrolisis. Beberapa enzim yang dapat digunakan untuk menghidrolisis protein adalah enzim dari pencernaan hewan seperti tripsin, kimotripsin dan pepsin, dari tanaman seperti bromelin dan papain atau enzim yang dihasilkan oleh bakteri misalnya alkalase dari Bacillus licheniformis ( $\mathrm{Li}$ et al., 2016). Keberhasilan untuk mendapatkan potongan peptida yang bersifat bioaktif sangat ditentukan oleh sumber protein dan spesifitas enzim, sehingga pemilihan enzim merupakan tahap penting untuk mendapatkan peptida bioaktif dan akan menentukan bioaktivitas peptida yang dihasilkan (Kumar et al., 2013). Bromelin dihasilkan dari buah nanas yang banyak tersedia di Indonesia. Kelebihan bromelin dibandingkan dengan protease tanaman yang lain adalah bromelin mudah diperoleh dan tersedia dari awal perkembangan buah sampai buah matang meskipun ada fluktuasi pada aktivitas proteolitiknya (Maurer, 2001). Protease dari buah lain seperti tin dan papaya, ficin dan papain hanya ditemukan ketika buah masih hijau dan protease menghilang setelah buah masak (Bartholomew et al., 2003). Selain itu, bromelin juga aktif baik dalam bentuk enzim murni maupun masih dalam bentuk jus buah nanas. Pemanfaatan bromelin untuk menghasilkan peptida bioaktif dari susu kambing belum pernah dilaporkan.

Bromelin termasuk dalam sistein protease yang dapat diisolasi dari buah nanas. Bromelin juga merupakan endoprotease yang memecah protein menjadi peptida (Arshad et al., 2014). Bromelin memecah protein pada ujung karbonil asam amino lisin, alanine, tirosin dan glisin (Godfrey dan Reichel, 1983). Bromelin dapat digunakan untuk memproduksi peptida bioaktif seperti peptida antimikroba dari protein ikan Meuschenia sp. yang dapat menghambat Staphylococcus aureus dan Bacillus cereus
(Salampessy et al., 2010) Hidrolisis protein oleh protease seperti bromelin menghasilkan hidrolisat yang mengandung campuran peptida yang bersifat bioaktif maupun yang tidak mempunyai aktivitas. Oleh karena itu, diperlukan fraksinasi pemekatan dan pemurnian peptida bioaktif. Beberapa metode dapat digunakan untuk mengisolasi peptida bioaktif yang diinginkan dan memisahkan dari protein yang tidak terhidrolisis atau kontaminan lainnya. Salah satunya adalah pemisahan menggunakan membran molecular weight cut off (MWCO). Filtrasi tersebut mampu memekatkan peptida yang diinginkan berdasarkan berat molekul tertentu (Vandanjon et al., 2007). Metode filtrasi tersebut dinilai mudah untuk digunakan dalam skala besar dengan biaya yang lebih murah dibandingkan dengan metode kromatografi cair (Muro et al., 2013).

Pada penelitian ini bromelin digunakan untuk menghidrolisis protein susu kambing dan selanjutnya hidrolisat yang dihasilkan diuji aktivitas antibakteri dan antioksidannya. Pada uji antioksidan digunakan dua metode yaitu pengujian menggunakan [2, 2'-azino-bis (3-ethylbenzthiazoline-6-sulphonic acid)] (ABTS) dan 2,2-diphenyl-1-picrylhydrazyl (DPPH) untuk membandingkan dan mendapatkan metode yang sesuai untuk sampel hidrolisat susu kambing. Hidrolisat tersebut mengandung peptidapeptida yang dapat berfungsi sebagai antibakteri sekaligus antioksidan dan akan membuka peluang untuk pemanfaatan peptida bioaktif dari susu kambing sebagai ingredien pangan fungsional di masa depan.

\section{BAHAN DAN METODE}

\section{Bahan}

Bahan yang digunakan pada penelitian ini adalah susu kambing peranakan Ettawa (PE) diperoleh dari peternakan kambing, Fakultas Peternakan Institut Pertanian Bogor. Buah nanas bogor mengkal diperoleh dari pasar di kota Bogor dan mikroorganisme yang digunakan pada penelitian ini adalah Escherichia coli (ATCC 25922), Salmonella enterica sub spesies enterica serovar Salmonella Typhimurium (ATCC 13311) dan Listeria monocytogenes (ATCC 15313).

\section{Persiapan susu kambing}

Lemak yang terkandung pada susu segar dipisahkan dengan sentrifugasi 6000×g (Hybrid refrigerated centrifuge, CAX-371, Tomy Seiko, Japan) pada suhu $4^{\circ} \mathrm{C}$ selama 15 menit. Susu bebas lemak selanjutnya dihidrolisis atau disimpan pada $-20^{\circ} \mathrm{C}$ sampai digunakan.

\section{Penentuan kadar protein}

Pengukuran kadar protein dilakukan menggunakan larutan Bradford (Quick start ${ }^{\mathrm{TM}}$ Bradford 
protein assay, Bio-Rad Inc, Philadelphia, USA). Kurva standar dibuat dengan mereaksikan $5 \mu \mathrm{L}$ larutan standar Bovine serum albumin (BSA) dengan berbagai konsentrasi dengan $95 \mu \mathrm{L}$ larutan Bradford. Perlakuan yang sama dilakukan pada sampel protein dan aquades sebagai blanko. Larutan didiamkan selama 5 menit dan diukur absorbansinya pada $\lambda=600 \mathrm{~nm}$ (Labsystems, original Multiscan Ex, Champaign, USA).

\section{Ekstraksi dan penentuan aktivitas enzim}

Bromelin diekstrak dengan menghancurkan buah nanas muda tanpa kulit menggunakan food processor. Jus yang diperoleh selanjutnya disaring menggunakan kertas saring Whatman No. 41 (Sigma- Aldrich, USA), ditambahkan aseton (SigmaAldrich, USA) dengan perbandingan 1:1 (v/v) dan disimpan pada suhu $4^{\circ} \mathrm{C}$ semalam. Larutan disentrifugasi (micro ultracentrifuge CS $150 \mathrm{NX}$, Hitachi, Japan) pada suhu $4^{\circ} \mathrm{C} 6000 \times g$ selama 15 menit. Endapan kemudian dicampur dengan phosphate buffer saline (PBS) $\mathrm{pH} \mathrm{7,4} \mathrm{dengan} \mathrm{perbandingan} \mathrm{1:1}$ (w/v) (Rowan et al., 1990). Penentuan aktivitas enzim dilakukan menggunakan metode Bergmeyer dan Grassel (1983) dengan mereaksikan $250 \mu \mathrm{L}$ kasein (Oxoid, UK) dengan konsentrasi 2\% (w/v) dengan $50 \mu \mathrm{L}$ enzim dan $250 \mu \mathrm{L}$ PBS $0,05 \mathrm{M} \mathrm{pH} 7$. Campuran reaksi diinkubasi pada suhu $37^{\circ} \mathrm{C}$ selama 10 menit kemudian ditambahkan $500 \mu \mathrm{L}$ TCA (Sigma-Aldrich, USA) 0,2 M. Larutan diinkubasi kembali pada suhu $37^{\circ} \mathrm{C}$ selama 10 menit, disentrifugasi $2000 \times g$ (centrifuge MRX-152, Tomy Seiko, Japan) selama 10 menit. Supernatan $375 \mu \mathrm{L}$ dicampurkan dengan $1250 \mu \mathrm{L} \mathrm{Na} \mathrm{CO}_{3} \quad 0,4 \mathrm{M}$ dan ditambahkan $250 \mu \mathrm{L}$ pereaksi Folin ciolcateau (Merck, Damstardt, Germany) dengan pengenceran 1:2 (v/v) dan diinkubasi pada suhu $37^{\circ} \mathrm{C}$ selama 20 menit. Absorbansi diukur dengan spektrofotometer (LKB Novaspec II, Pharmacia-Biotech) pada $\lambda 578 \mathrm{~nm}$. Aquades digunakan sebagai blanko dan sebagai standar digunakan larutan tirosin (Sigma-Aldrich, USA) $5 \mathrm{mM}$. Satu unit aktivitas didefinisikan sebagai jumlah enzim yang dapat menghasilkan satu $\mu \mathrm{mol}$ tirosin permenit pada kondisi pengujian.

\section{Hidrolisis protein susu kambing}

Hidrolisis dilakukan pada suhu $50^{\circ} \mathrm{C}, \mathrm{pH} 6$ selama 60 menit dengan aktivitas bromelin 0,1 unit/mL dengan perbandingan enzim:substrat 1:4 $(v / v)$. Hidrolisat yang diperoleh sebagian digunakan langsung untuk uji antibakteri dan antioksidan, sebagian lagi difraksinasi menggunakan membran cut off $10 \mathrm{kDa}$ (AMICON Ultra centrifugal units, Merck Millipore Ltd., Darmstadt, Germany). Masingmasing fraksi peptida yang diperoleh yaitu $<10 \mathrm{kDa}$ dan $>10 \mathrm{kDa}$ diuji aktivitas antimikroba dan antioksidannya.

\section{Sodium dodecyl sulphate-polyacrilamide gel electrophoresis (SDS-PAGE)}

Penentuan berat molekul peptida dilakukan menggunakan SDS-PAGE (Laemmli, 1970) dengan komposisi gel penahan $4 \%$ dan gel pemisah $10 \%$ untuk protein dan 18\% untuk peptida (Anderson et al., 1983). Elektroforesis dilakukan pada tegangan 100 Volt. Pewarnaan dilakukan menggunakan commasie blue (Sigma-Aldrich, USA) untuk protein susu kambing dan silver staining kit (Sigma-Aldrich, USA) untuk peptida.

\section{Karakterisasi peptida dengan reverse-phase high performance liquid chromatography (RP- HPLC) \\ Karakterisasi peptida dalam hidrolisat dilaku-} kan menggunakan HPLC (Waters, Massachuset, USA) berdasarkan metode McCann et al. (2006). Sampel hidrolisat dimasukkan ke dalam kolom HPLC C-18 $(5 \mu \mathrm{m}, 4.6 \times 250 \mathrm{~mm}$, Xterra, Waters, Massachuset, USA). Elusi hidrolisat dilakukan dengan menggunakan gradient acetonitril (ACN) (Sigma-Aldrich, USA) dan trifuoroacetic acid (TFA) (Sigma-Aldrich, USA) yang terdiri dari larutan $A$ 0,1\% TFA (v/v) dalam ACN dan larutan B 0,1\% (v/v) TFA dalam air tanpa ion (deionized water). Sistem HPLC diseimbangkan dengan 95\% larutan B selama 5 menit, diikuti gradien linier $5-45 \%(\mathrm{v} / \mathrm{v})$ larutan $\mathrm{A}$ selama 20 menit untuk mengelusi peptida dan kemudian diseimbangkan kembali dengan 95\% (v/v) larutan B selama 5 menit. Absorbansi diukur pada panjang gelombang $215 \mathrm{~nm}$ yang merupakan panjang gelombang spesifik untuk peptida (Driver dan Raynie, 2007).

\section{Uji antibakteri}

Pengujian antibakteri dilakukan berdasarkan metode Lopez-Exposito et al. (2007) dengan mencampurkan $100 \mu \mathrm{L}$ bakteri uji $10^{6} \mathrm{CFU} / \mathrm{mL}$ dengan $100 \mu \mathrm{L}$ peptida dengan konsentrasi $1 \mathrm{mg}$ protein $/ \mathrm{mL}$ dalam mikroplate kemudian diinkubasi pada suhu $37^{\circ} \mathrm{C}$ selama 2 jam. Setelah 2 jam, campuran diencerkan dan masing-masing pengenceran ditumbuhkan pada media Mueller Hinton Agar (Oxoid, UK) dan diinkubasi kembali pada suhu $37^{\circ} \mathrm{C}$ selama 24 jam. Jumlah koloni yang tumbuh dihitung. Pengujian dilakukan dengan 3 kali ulangan.

\section{Pengujian antioksidan}

Pengujian antioksidan dilakukan berdasarkan metode Thaipong et al. (2006) menggunakan [2, 2'azino-bis (3-ethylbenzthiazoline-6-sulphonic acid)] (ABTS) (Sigma-Aldrich, USA) dan 2,2-diphenyl-1picrylhydrazyl (DPPH) (Sigma-Aldrich, USA). Larutan stok ABTS dibuat dengan melarutkan ABTS dalam deionized water sehingga diperoleh konsentrasi $7,4 \mathrm{mM}$. Larutan stok potassium persulfat (Sigma-Aldrich, USA) dibuat dengan konsentrasi 2,6 
mM. Untuk larutan yang akan direaksikan dibuat dengan mencampurkan larutan stok ABTS dengan larutan stok potassium persulfat dengan perbandingan 1:1 (v/v). Reaksi oksidasi dilakukan dalam kondisi gelap selama 16-18 jam. Selanjutnya larutan diencerkan dengan deionized water

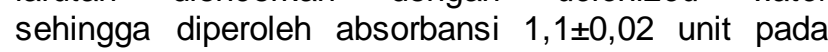
panjang gelombang $405 \mathrm{~nm}$. Sebanyak $100 \mu \mathrm{L}$ peptida sebelum atau setelah fraksinasi dengan konsentrasi $0,1 \mathrm{mg}$ protein/mL dicampurkan dengan $200 \mu \mathrm{L}$ radikal ABTS dalam mikroplate dan diletakkan pada suhu ruangan selama 10 menit. Pengukuran absorbansi dilakukan pada $\lambda 405 \mathrm{~nm}$ (Labsystems, original Multiscan Ex, Champaign, USA). Untuk standar antioksidan digunakan vitamin C p.a. pada berbagai konsentrasi. Pengujian menggunakan DPPH dilakukan berdasarkan kombinasi metode Thaipong et al. (2006) dan Clarke et al. (2013) dengan menambahkan etanol $96 \%$ pada DPPH sehingga diperoleh absorbansi $1,1 \pm 0,05$ pada $\lambda=540 \mathrm{~nm}$. Sebanyak $100 \mu \mathrm{L}$ hidrolisat dan fraksi peptida dengan konsentrasi $0,1 \mathrm{mg}$ protein $/ \mathrm{mL}$ ditambahkan dengan $200 \mu \mathrm{L}$ DPPH, dibiarkan selama 30 menit dan absorbansi campuran diukur pada $\lambda 540 \mathrm{~nm}$ (Labsystems, original Multiscan Ex, Champaign, USA). Untuk standar antioksidan digunakan vitamin C p.a pada berbagai konsentrasi. Aktivitas antioksidan pada uji ABTS dan DPPH dihitung berdasarkan persamaan:

Aktivitas antioksidan $(\%)=\frac{\text { A blangko-A sample }}{A \text { blangko }} \times 100 \%$

Keterangan:

A blangko : absorbansi hasil reaksi larutan ABTS/DPPH dan deionized water

A sampel : selisih absorbansi antara sampel (hasil reaksi peptida dan $\mathrm{ABTS} / \mathrm{DPPH}$ ) dan kontrol peptida

\section{Uji hemolisis}

Uji hemolisis dilakukan berdasarkan metode Lorenzon et al. (2012) dan Nguyen et al. (2011). Sel darah merah ayam dicuci dengan $0,01 \mathrm{M}$ Tris- $\mathrm{HCl}$ ( $\mathrm{pH} 7,4)$ yang mengandung $0,15 \mathrm{M} \mathrm{NaCl}$ (Tris-salin) kemudian disentrifugasi pada $1000 \times g$ (Microspin 12, Biosan, EU) supernatan dibuang dan pelet dicuci lagi sebanyak 2 kali. Suspensi $0,1 \%$ sel darah merah dibuat dengan melarutkan kembali sel darah merah dengan larutan Tris-salin. Sebanyak $100 \mu \mathrm{L}$ peptida ditambahkan dengan $100 \mu \mathrm{L}$ sel darah merah $0,1 \%$, diinkubasi selama 2 jam pada suhu $37^{\circ} \mathrm{C}$, kemudian disentrifugasi pada $2000 \times \mathrm{g}$ (Microspin 12, Biosan, EU) selama 5 menit. Supernatan dipisahkan dan diambil $100 \mu \mathrm{L}$, dimasukkan ke dalam mikroplate. Absorbansi diukur pada panjang gelombang $540 \mathrm{~nm}$ (Labsystems, original Multiscan Ex, Champaign, USA). Triton X-100
(Sigma-Aldrich, USA) digunakan sebagai kontrol positif untuk lisis $100 \%$ dan Trissalin sebagai kontrol negatif. Pengujian dilakukan dengan 3 kali ulangan.

\section{HASIL DAN PEMBAHASAN}

\section{Profil susu kambing dan peptida dengan SDS- PAGE}

Hasil analisis SDS-PAGE susu kambing seperti terlihat pada Gambar 1, jalur 1. Apabila dibandingkan dengan SDS-PAGE susu kambing oleh Munoz et al. (2004) pita protein pada penelitian terlihat lebih banyak, kemungkinan disebabkan konsentrasi sampel dan pewarnaan yang menyebabkan pita protein pada Munoz et al. (2004) sangat tipis dan kurang jelas. Menurut Munoz et al. (2004) pita antara 20-35 kDa teridentifikasi sebagai casein dan tiga pita lainnya merupakan $\alpha$-lactalbumin, $\beta$ lactoglobulin dan serum albumin (Gambar 1, jalur G).

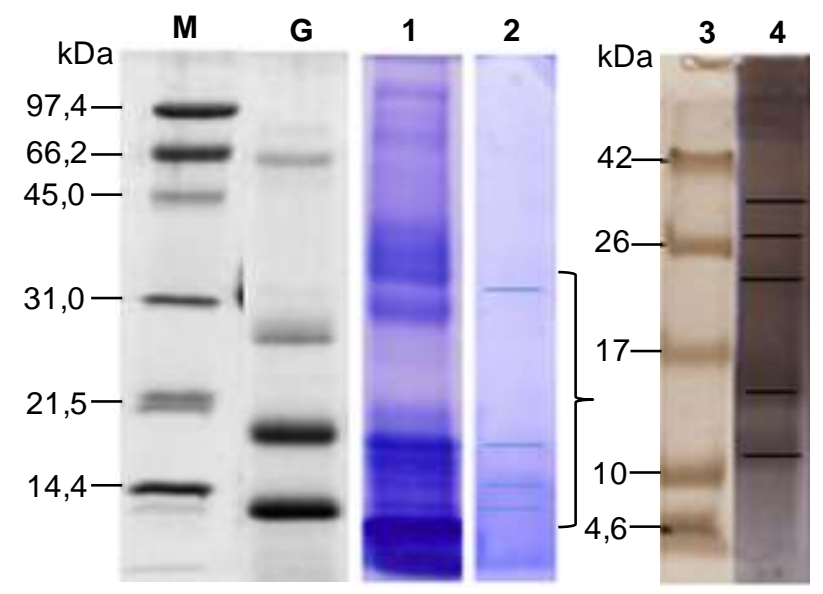

Gambar 1. SDS-PAGE susu kambing, M: marker, G: susu kambing (Munoz et al., 2004). 1. Susu kambing sebelum dihidrolisis, 2. Susu kambing setelah dihidrolisis dengan enzim bromelin selama 60 menit, konsentrasi gel $10 \%$, pewarnaan dengan coomassie blue. 3. Marker, 4. Peptida hasil hidrolisis susu kambing menggunakan enzim bromelin selama 60 menit, konsentrasi gel $18 \%$, pewarnaan dengan pewarna silver

Hidrolisis protein susu kambing dengan bromelin menghasilkan peptida-peptida dengan berat molekul rendah (Gambar 1). Berdasarkan kandungan proteinnya, protein susu telah terhidrolisis $90 \%$ (dari kadar protein susu kambing $50 \mathrm{mg} / \mathrm{mL}$ menjadi $5 \mathrm{mg} / \mathrm{mL}$ pada hidrolisat). Hasil tersebut menandakan bahwa hampir semua protein susu telah terhidrolisis. Peptida-peptida yang dihasilkan mempunyai berat molekul antara 12-35 kDa (Gambar 1, jalur 4). 


\section{Karakterisasi peptida dengan RP-HPLC}

Karakterisasi dilakukan menggunakan RPHPLC dengan panjang gelombang $215 \mathrm{~nm}$ yang spesifik untuk peptida. Kromatogram menunjukkan adanya 4 puncak peptida (Gambar 2). Berdasarkan waktu retensinya yaitu antara 1.9-2.6 menit menunjukkan peptida tersebut terdeteksi pada waktu fase gerak dalam kondisi hidrofilik, menandakan bahwa peptida-peptida tersebut bersifat hidrofilik. Permukaan sisi hidrofobik bertanggungjawab pada pembentukan dan pertahanan struktur spasial, interaksi peptida, termasuk ikatan dengan membran sel, pengenalan antar peptida atau protein dan pembentukan komplek dengan suatu senyawa (Mundi dan Aluko, 2014). Pada peptida antimikroba, informasi tentang karakter hidrofobisitas akan memberikan pemahaman lebih jauh tentang mekanisme kerja dan berpengaruh pada bioaktivitasnya (Zhao et al., 2013). Semakin besar hidrofobisitas dan muatan positif suatu peptida maka semakin besar pula kemampuan antimikrobanya (Yin et al., 2012). Hidrofobisitas juga menentukan spesifisitas peptida antibakteri sehingga hanya bakteri patogen yang menjadi target sedangkan flora normal tidak terpengaruh. Menurut Huang et al. (2014), peptida antibakteri dapat didesain untuk meningkatkan spesifitas dan aktivitasnya melalui penggantian asam amino hidrofobik atau hidrofilik.

Pada penelitian ini protein dan peptida-peptida pada hidrolisat bersifat hidrofilik. Meskipun demikian, hidrolisat dan hasil fraksinasinya masih menunjukkan aktivitas antimikroba. Menurut Yin et al. (2012) aktivitas antimikroba suatu peptida ditentukan oleh keseimbangan antara hidrofobisitas dan distribusi muatan. Hidrofobisitas yang tinggi justru dapat meningkatkan self-association yang dapat mengurangi kemampuan antimikrobanya. Distribusi muatan positif yang seimbang pada ujung terminal peptida dapat mengembalikan kemampuan antimikroba tersebut. Hidrolisat hasil hidrolisis protein susu kambing dengan bromelin pada penelitian ini belum dipisahkan dan disekuensing sehingga masih sulit untuk menentukan pengaruh hidrofilisitas terhadap aktivitas antimikrobanya.

\section{Aktivitas antibakteri}

Hasil pengujian antibakteri menunjukkan bahwa peptida sebelum dan sesudah fraksinasi dapat menghambat pertumbuhan E. coli, S. Typhimurium dan L. monocytogenes (Gambar 3). Pada E. coli, fraksi $>10 \mathrm{kDa}$ menunjukkan penghambatan yang lebih baik dibandingkan dengan peptida sebelum fraksinasi maupun fraksi $<10 \mathrm{kDa}$. Untuk $S$. Typhimurium dan L. monocytogenes, fraksinasi dapat meningkatkan aktivitas antibakterinya.

Hasil pengujian antibakteri juga menandakan bahwa peptida yang berukuran besar maupun kecil mempunyai aktivitas antibakteri. Aktivitas antibakteri peptida tersebut berbeda dengan hasil hidrolisis kasein susu sapi dengan protease Lactobacillus acidophilus DPC6026 yang menunjukkan bahwa peptida dengan ukuran $>10 \mathrm{kDa}$ tidak mempunyai aktivitas antibakteri (Hayes et al., 2006). Perbedaan sumber protein dan spesifitas enzim menyebabkan perbedaan ukuran dan aktivitas peptida yang dihasilkan. Berdasarkan aktivitas antibakteri, penghambatan tertinggi terjadi pada $L$. monocytogenes fraksi $<10 \mathrm{kDa}$. Pada L. monocytogenes, aktivitas hidrolisat lebih tinggi daripada fraksi $>10 \mathrm{kDa}$ dan aktivitas tertinggi pada fraksi $<10 \mathrm{kDa}$. Berdasarkan hasil tersebut kemungkinan peptida yang aktif sebagai antimikroba banyak terkandung pada fraksi $<10 \mathrm{kDa}$, sehingga ketika dipisahkan maka aktivitas fraksi $>10 \mathrm{kDa}$ lebih rendah dibandingkan dengan hidrolisat yang merupakan campuran fraksi $<10 \mathrm{kDa}$ dan $>10 \mathrm{kDa}$. Menurut Lopez-Solanilla et al. (2003) kerentanan L. monocytogenes terhadap peptida antimikroba juga tergantung pada suhu. L. monocytogenes menjadi sangat rentan terhadap peptida antimikroba pada suhu $37^{\circ} \mathrm{C}$ dan menjadi resisten pada suhu $20^{\circ} \mathrm{C}$.

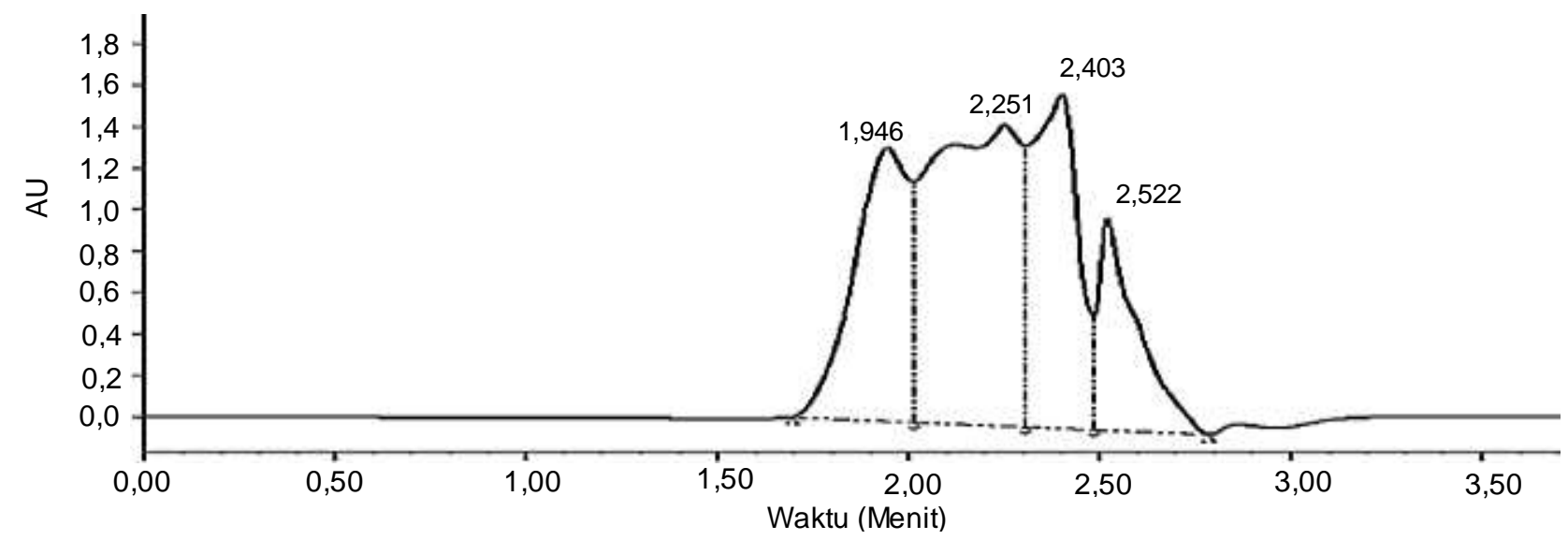

Gambar 2. Kromatogram Reverse-Phase High Performance Liquid Chromatography (RP-HPLC) dari peptida hasil hidrolisis susu kambing dengan enzim bromelin selama 60 menit pada $\lambda=215 \mathrm{~nm}$ 

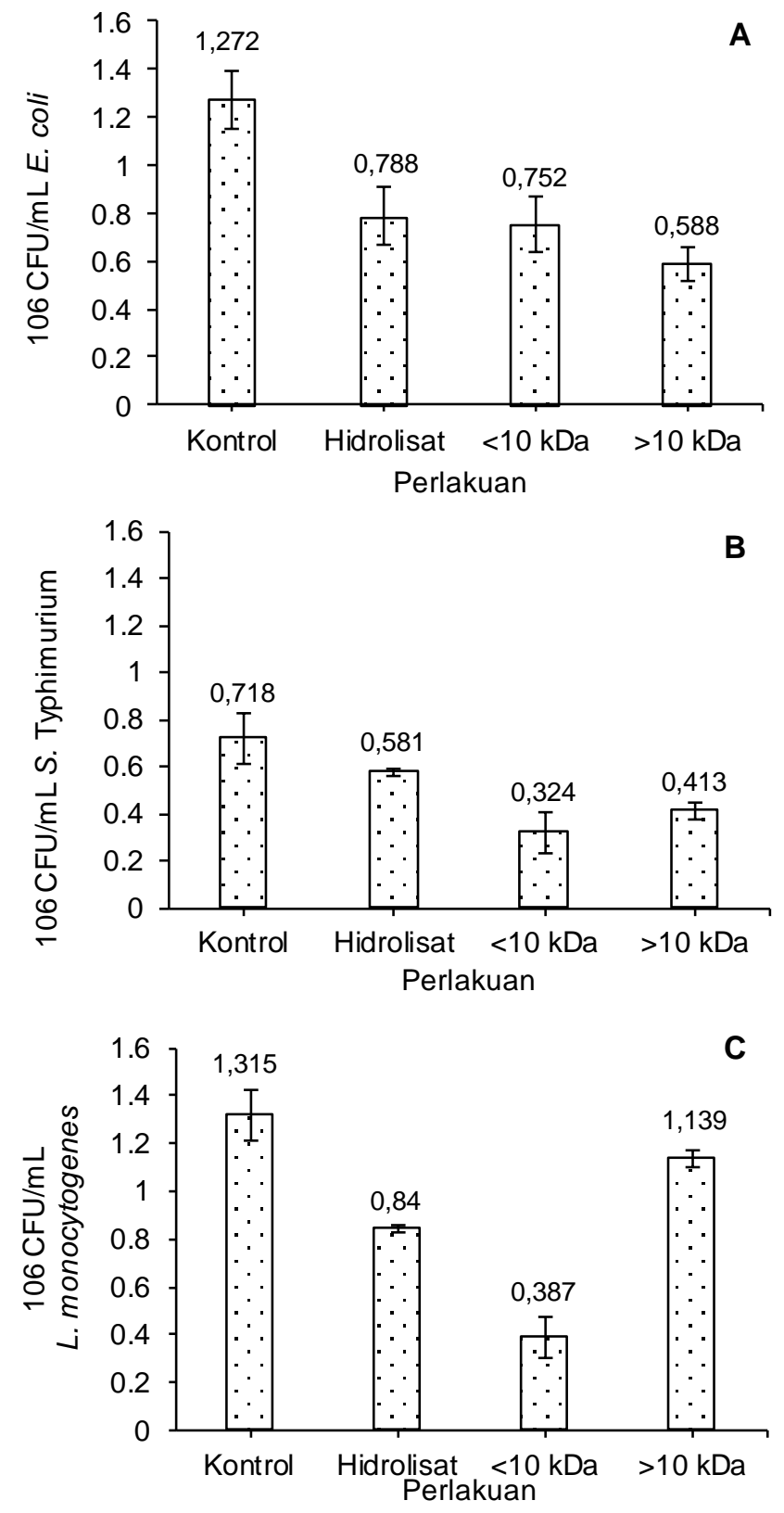

Gambar 3. Hasil uji antibakteri terhadap peptida hasil hidrolisis susu kambing sebelum fraksinasi (hidrolisat) dan setelah fraksinasi menggunakan membran cut off $10 \mathrm{kDa}$. Pengujian dilakukan terhadap E. coli (A), S. Typhimurium (B) dan $L$. monocytogenes (C)

Pada penelitian ini inkubasi dilakukan pada suhu $37^{\circ} \mathrm{C}$ yang mungkin membuat aktivitas peptida hasil hidrolisis susu kambing dengan bromelin fraksi $<10 \mathrm{kDa}$ terhadap $L$. monocytogenes lebih tinggi dibandingkan aktivitasnya terhadap $E$. coli dan $S$. Typhimurium. L. monocytogenes merupakan bakteri psikrofilik yang mampu tumbuh dan berkembang biak pada suhu rendah (Saha et al., 2015). L. monocytogenes mengembangkan resistensi terhadap peptida antimikroba pada suhu yang lebih rendah dengan mengubah komposisi membran sitoplasma dan meningkatkan ketebalan dinding sel (Mendoza et al., 1999). Lebih lanjut, Dare et al. (2014) menyatakan bahwa proporsi lipida seperti lisillcardiolipin dan lisilfosfatidilgliserol berubah dengan turunnya suhu lingkungan dan meningkatkan kemampuan bertahan $L$. monocytogenes dari peptida antimikroba.

Pada Gambar 3. terlihat bahwa fraksi $>10 \mathrm{kDa}$ efektif pada $S$. aureus, sedangkan fraksi $<10 \mathrm{kDa}$ lebih efektif pada $S$. Typhimurium dan $L$. monocytogenes. Dari hasil tersebut terlihat bahwa fraksi peptida tertentu spesifik terhadap bakteri tertentu pula. Menurut Mondhe et al. (2014) peptida antibakteri secara alamiah atau hasil modifikasi bersifat spesifik spesies, yaitu peptida tersebut hanya efektif terhadap bakteri tertentu sehingga peptida dapat membunuh bakteri patogen tanpa harus mematikan flora normal. Peptida antibakteri berinteraksi dengan membran sel bakteri melalui interaksi muatan positif peptida dengan muatan negatif pada permukaan sel bakteri. Mekanisme selanjutnya tergantung pada tipe peptida. Secara umum dapat dipisahkan peptida yang bekerja dengan mempengaruhi permeabilitas membran dan peptida yang bekerja di dalam sitoplasma. Peptida yang bekerja dengan mempengaruhi permeabilitas membran dapat terjadi dengan cara membuat pori atau dengan cara melarutkannya (bekerja seperti halnya deterjen) (Mihajlovic dan Lazaridis, 2010). Mekanisme lain adalah peptida antibakteri masuk ke dalam sitoplasma dan menghambat fungsi intraseluler seperti menghambat sintesis DNA, RNA dan reaksi enzimatis tanpa mengganggu stabilitas membran (Jenssen et al., 2006).

\section{Aktivitas antioksidan}

Aktivitas antioksidan peptida sebelum dan sesudah fraksinasi diuji dengan mengukur kemampuannya untuk menetralisasi radikal ABTS dan DPPH. Warna pada radikal ABTS dan DPPH akan berkurang dengan kehadiran antioksidan yang mendonorkan ion hidrogen atau yang dapat memecah rantai senyawa radikal (Correa et al., 2011). Hasil pengujian antioksidan seperti terlihat pada Gambar 4. Pada pengujian dengan ABTS, aktivitas antioksidan sebelum fraksinasi dan fraksi $<10 \mathrm{kDa}$ hampir sama yaitu $99 \%$ dan $100 \%$. Untuk fraksi $>10$ $\mathrm{kDa}$ lebih rendah yaitu $97 \%$. Jadi fraksi yang paling aktif adalah fraksi peptida $<10 \mathrm{kDa}$.

Pada pengujian antioksidan dengan DPPH menunjukkan bahwa fraksi $<10 \mathrm{kDa}$ mempunyai aktivitas antioksidan yang lebih tinggi daripada sebelum fraksinasi dan fraksi $>10 \mathrm{kDa}$. Apabila dibandingkan dengan hasil hidrolisis kacang merah menunjukkan bahwa peptida hasil hidrolisis susu kambing dengan enzim bromelin $<10 \mathrm{kDa}$ mem- 
punyai aktivitas antioksidan terhadap radikal DPPH yang lebih tinggi. Pada peptida dari kacang merah dengan konsentrasi $1 \mathrm{mg}$ protein/mL mempunyai aktivitas antioksidan 15\% (Mundi dan Aluko, 2014), sedangkan aktivitas peptida dari susu kambing fraksi $<10 \mathrm{kDa} 14 \%$ pada konsentrasi $0,1 \mathrm{mg}$ protein $/ \mathrm{mL}$.
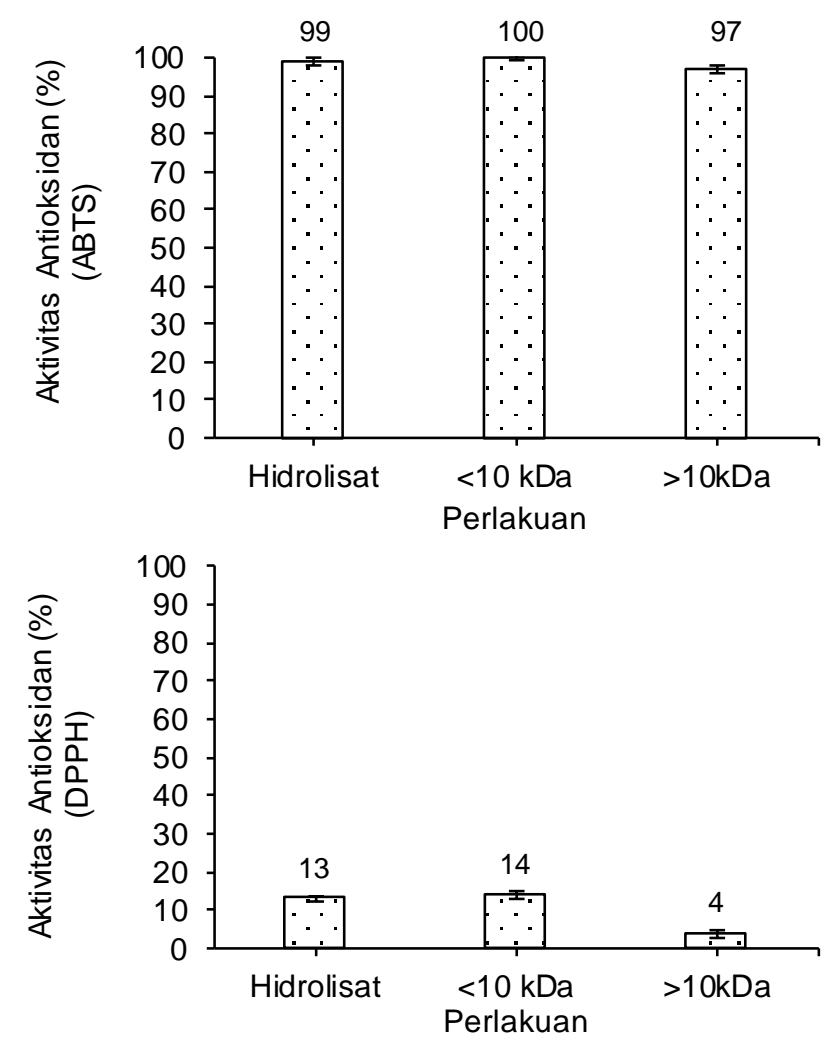

Gambar 4. Aktivitas antioksidan peptida terhadap radikal $A B T S$ dan $D P P H$ sebelum fraksinasi (hidrolisat) dan sesudah fraksinasi menggunakan membran cut off $10 \mathrm{kDa}$

Pada pengujian ABTS maupun DPPH, fraksi $>10 \mathrm{kDa}$ mempunyai aktivitas antioksidan yang lebih kecil daripada peptida sebelum fraksinasi maupun fraksi $<10 \mathrm{kDa}$, sedangkan aktivitas antioksidan tertinggi pada fraksi $<10 \mathrm{kDa}$. Berdasarkan hasi tersebut kemungkinan peptida yang aktif lebih banyak pada fraksi <10 kDa. Fraksinasi akan menurunkan rasio peptida aktif pada fraksi $>10 \mathrm{kDa}$ sehingga aktivitasnya menjadi lebih rendah sedangkan untuk fraksi $<10 \mathrm{kDa}$ fraksinasi justru lebih mengkonsentrasikan peptida bioaktifnya. Ultrafiltrasi menggunakan membran molecular weight cut off (MWCO) memungkinkan untuk memekatkan peptida dengan berat molekul tertentu dengan menghilangkan konsentrasi garam dan kontaminan (Vandanjon et al., 2007), sehingga aktivitasnya meningkat. Menurut Picot et al. (2010), fraksinasi peptida menggunakan membran MWCO merupakan cara yang efektif untuk memekatkan peptida antioksidan, tetapi dalam prosesnya masih memerlukan optimasi. Selektivitas membran yang digunakan bukan hanya memisahkan peptida berdasarkan ukuran tetapi juga berdasarkan gugus aromatik (Picot et al., 2010) dan muatan (Doyen et al., 2011) yang berpengaruh pada bioaktivitasnya. Menurut Udenigwe dan Aluko (2011) asam amino yang mengandung sulfur, asam dan hidrofobik mempunyai aktivitas antioksidan yang kuat terhadap radikal DPPH dan $\mathrm{H}_{2} \mathrm{O}_{2}$. Berlett dan Levine (2014) menambahkan bahwa asam amino metionin, sistein dan aromatik seperti tirosin, histidin, fenilalanin dan triptofan menunjukkan aktivitas antioksidan jauh lebih tinggi dibandingkan asam amino yang lain. Untuk aktivitas antioksidan terhadap radikal superoksida hanya lisin dan leusin yang menunjukkan aktivitas tinggi. Sebaliknya, asam amino bermuatan positif dalam hidrolisat justru menurunkan aktivitas antioksidan pada uji $\mathrm{Fe}$ reducing power, DPPH dan $\mathrm{H}_{2} \mathrm{O}_{2}$ (Udenigwe dan Aluko, 2011). Keberadaan asam amino yang bertanggungjawab terhadap antioksidan terutama fenilalanin dan histidin pada susu kambing cukup tinggi (Sabahelkheir et al., 2012) menandakan kemungkinan keberadaaan peptida yang bersifat antioksidan juga cukup tinggi.

Aktivitas antioksidan pada pengujian dengan ABTS menghasilkan nilai yang lebih besar dibandingkan dengan hasil uji DPPH. Radikal DPPH lebih stabil dibandingkan dengan radikal ABTS yang menyebabkan DPPH lebih sulit dinetralisasi. Selain itu beberapa antioksidan bereaksi lebih cepat ketika diuji menggunakan metode lain dan bereaksi lebih lambat pada DPPH serta menghasilkan kisaran reaksi yang lebih kecil (Prior et al., 2005). DPPH larut dalam pelarut organik yang lebih sesuai untuk senyawa lipofilik atau senyawa yang mempunyai kandungan lipid tinggi, sedangkan ABTS kompatibel dengan senyawa hidrofilik maupun hidrofobik (Damgaard et al., 2014). Karakterisasi hidrolisat menggunakan HPLC menunjukkan bahwa hidrolisat didominasi oleh peptida hidrofilik sehingga memberikan hasil uji DPPH yang lebih kecil daripada hasil uji ABTS. Berdasarkan hasil tersebut pengujian antioksidan menggunakan DPPH kurang sesui untuk digunakan pada hidrolisat bromelin susu kambing.

Hidrofobisitas menjadi faktor penting yang berperan dalam aktivitas antioksidan suatu peptida (Mundi dan Aluko, 2014). Seperti telah dilaporkan oleh Pownall et al. (2010) aktivitas antioksidan lebih berhubungan dengan kandungan total asam amino hidrofobik daripada ukuran peptida. Pendapat yang sama dilaporkan oleh Ajibola et al. (2011) yang menyatakan bahwa aktivitas yang tinggi pada fraksi peptida $<1 \mathrm{kDa}$ dari biji bengkuang disebabkan oleh jumlah total asam amino hidrofobik dan aromatik. Pada penelitian ini peptida yang terkandung pada hidrolisat bersifat hidrofilik. Selain hidrofobisitas, 
muatan dan komposisi asam amino aromatik juga menjadi penentu aktivitas antioksidan (Udenigwe dan Aluko, 2011). Meskipun peptida dalam hidrolisat bersifat hidrofilik, kandungan asam amino aromatik pada susu kambing cukup tinggi yaitu (dalam mg asam amino/g total asam amino) tirosin $(38,2)$, histidine $(31,1)$, dan fenilalanin (62) (Sabahelkheir et al., 2012). Keberadaan asam amino dengan aktivitas antioksidan tinggi seperti metionin $(5,5)$, sistein $(20,5)$, lisin $(26,3)$ dan leusin $(146,2)$ (Sabahelkheir et al., 2012) juga ikut berperan dalam peningkatan aktivitas antioksidan peptida dalam hidrolisat.

\section{Aktivitas hemolisis}

Uji hemolisis biasa dilakukan untuk mengetahui toksisitas peptida antimikroba karena sensitivitasnya untuk mengevaluasi kerusakan membran sel eukariot (sel inang) (Lorenzon et al., 2012). Seperti terlihat pada Gambar 5, peptida hasil hidrolisis protein susu kambing sebelum fraksinasi hanya sedikit menimbulkan hemolisis. Peptida setelah fraksinasi bahkan bernilai negatif yang menandakan bahwa nilai hemolisis lebih kecil daripada kontrol sel darah merah. Kontrol sel darah merah seperti diketahui juga mengandung enzim tertentu yang menyebabkan autolisis sel darah merah. Nilai negatif menandakan bahwa keberadaan peptida dapat membantu mengurangi autolisis pada sel darah merah. Hasil tersebut mengindikasikan bahwa peptida hasil hidrolisis protein susu kambing dengan bromelin aman untuk diaplikasikan.

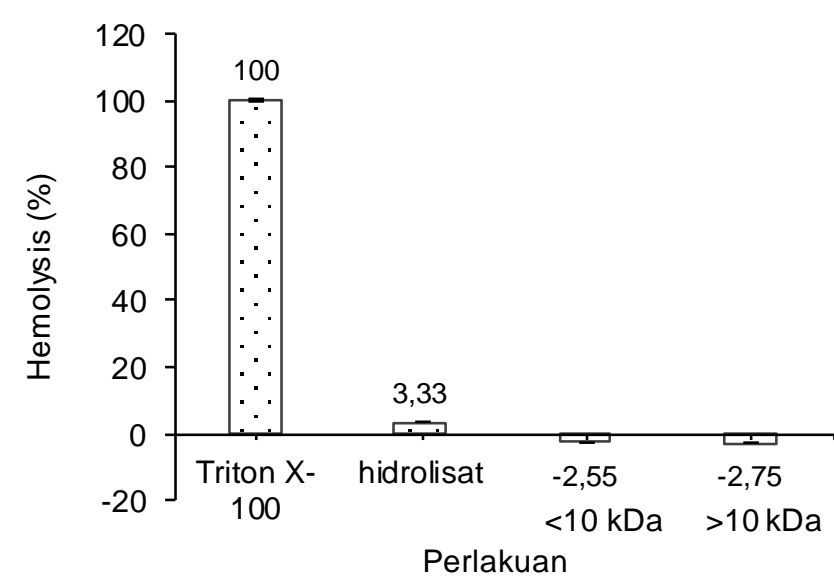

Gambar 5. Hasil uji hemolisis terhadap peptida sebelum fraksinasi (hidrolisat) dan sesudah fraksinasi dengan membran cut off $10 \mathrm{kDa}$. Nilai hemolisis negatif disebabkan oleh pengurangan terhadap kontrol negatif sel darah merah yang mempresentasikan hemolisis $0 \%$. Triton $\mathrm{X}-100$ sebagai kontrol positif hemolysis $100 \%$

\section{KESIMPULAN}

Peptida hasil hidrolisis susu kambing dengan enzim bromelin dapat menghambat pertumbuhan bakteri E. coli, $S$. Typhimurium dan L. monocytogenes. Peptida tersebut juga dapat berfungsi sebagai antioksidan yang ditandai dengan kemampuan untuk menetralisasi radikal ABTS dan DPPH. Fraksinasi menggunakan membran cut off $10 \mathrm{kDa}$ dapat meningkatkan aktivitas antimikroba maupun antioksidan. Hasil uji hemolisis menunjukkan bahwa peptida tersebut tidak menyebabkan hemolisis bahkan dapat mengurangi autolisis pada sel darah merah.

\section{UCAPAN TERIMA KASIH}

Penelitian ini terlaksana atas biaya penelitian Badan Penelitian dan Pengembangan Pertanian, Kementrian Pertanian APBN 2013 No 18023D dan Direktorat Jendral Pendidikan Tinggi, BOPTN 2013 No 2013.089.521219.

\section{DAFTAR PUSTAKA}

Almaas H, Eriksen E, Sekse C, Comi I, Flengsrud R, Holm $H$, Jensen $E$, Jacobsen $M$, Langsrud $T$, Vegarud GE. 2011. Antibacterial peptides derived from caprine whey proteins, by digestion with human gastrointestinal juice. Brit J Nutr 106: 896-905. DOI: 10.1017/S000711 4511001085.

Anderson BL, Berry RW, Telser A. 1983. A sodium dodecyl sulfate-polyacrylamide gel electrophoresis system that separates peptides and proteins in the molecular weight range of 2500 to 90,000. Anal Biochem 132: 365-375. DOI: 10.1016/0003-2697(83)90022-2.

Ajibola CF, Fashakin JB, Fagbemi TN, Aluko RE. 2011. Effect of peptida size on antioxidant properties of African yam bean seed (Sphenostylis stenocarpa) protein hydrolysate fractions. Int J Mol Sci 12: 6685-6702. DOI: 10.33 90/ijms 12106685.

Arshad ZIM, Amid A, Yusof F, Jaswir I, Ahmad K, Loke SP. 2014. Bromelain: an overview of industrial application and purification strategies. Appl Microbiol Biotechnol 98: 7283-7297. DOI: 10.1007/s00253-014-5889-y.

Bartholomew DP, Paull RE, Rohrbach KG. 2003. The Pineapple: Botany, Production and Uses. 1-301. $1^{\text {st }}$ Ed. Wallingford-UK: CABI Publishing. 
Bergmeyer HU, Bergmeyer J, Grassel M. 1983. Methods of Enzymatic Analysis. $2^{\text {nd }}$ Ed. 118-126. Weinheim: Verlag Chemie, USA.

Berlett BS, Levine RL. 2014. Designing antioxidant peptides. Redox Rep 19: 80-86. DOI: 10.1179/ 1351000213Y.0000000078.

Clarke G, Ting KN, Wiart C, Fry J. 2013. High correlation of 2,2 -dipheenyl-1-picrylhydrazyl (DPPH) radical scavenging, ferric reducing activity potential and total phenolics content indicated redundancy in use of all three assay in use of all three assay to screen for antioxidant activity of extracts of plants from the Malaysian reinforest. Antioxidants 2: 1-10. DOI: 10.3390/antiox2010001.

Correa AP, Daroit DJ, Coelho J, Meira SM, Lopes FC, Segalin J, Risso PH, Brandelli A. 2011. Antioxidant, antihypertensive and antimicro-bial properties of ovine caseinate hydrolyzed with microbial protease. J Sci Food Agr 91: $2247-$ 2254. DOI: $10.1002 /$ jsfa.4446.

Damgaard TD, Otte JAH, Meinert L, Jensen K, Lametsch R. 2014. Antioxidant capacity of hydrolyzed porcine tissues. Food Sci Nutr 2: 282-288. DOI: 10.1002/fsn3.106.

Doyen A, Beaulieu L, Saucier L, Pouliot Y, Bazinet L. 2011. Impact of ultrafiltration membrane material on peptida separation from a snow crab byproduct hydrolysate by electrodialysis with ultrafiltration membranes. J Agric Food Chem 59: 1784-1792. DOI: 10.1021/jf103739 $\mathrm{m}$.

Dare K, Shepherd J, Roy H, Seveu S, Ibba M. 2014. LysPGS formation in Listeria monocytogenes has broad roles in maintaining membrane integrity beyond antimicrobial peptide resistance. Virulance 5: 534-546. DOI: 10.4161/viru.28359.

Driver JL, Raynie DE. 2007. Method Development for Biomolecules in HPLC Method Development for Pharmaceutical. 430-435. Ahuja SA, Rasmussen (Eds) Elsevier Inc. Italy.

Godfrey T, Reichel J. 1983. Industrial Enzymology. Macmillan Publishers Ltd., 1-4 Surrey ,UK.

Hayes M, Ross RP, Fitzgerald FG, Hill C, Stanton C. 2006. Casein-derived antibacterial peptidas generated by Lactobacillus acidophilus DPC6026. Appl Env Microb 72: 2260-2264. DOI: 10.1128/ AEM.72.3.2260-2264.2006.

Huang Y, He L, Li G, Zhai N, Jiang H, Chen Y. 2014. Role of helicity of $\alpha$-helical antimicrobial peptidas to improve specificity. Protein Cell 5: 631642. DOI: 10.1007/s13238-014-0061-0.

Jenssen H, Hamill P, Hancock REW. 2006. Peptide antimicrobial agent. Clin Microbiol Rev 19: 91511. DOI: 10.1128/CMR.00056-05.
Kumar S, Chouhan S, Sanghi A, Teotia UVS. 2013. Antioxidative effect of yak milk caseinate hydrolyzed with three different proteases. Vet World 6: 799-802. DOI: 10.14202/vetworld. 2013.799802.

Laemmli UK. 1970. Cleavage of structural protein during the assembly of the head of bacteriophage T4. Nature 227: 680-685. DOI: 10.1038/ $227680 \mathrm{a} 0$.

Li Z, Jiang A, Yue T, Wang Y, Su J. 2013. Purification and identification of five novel antioxidant peptidas from goat milk casein hydrolysates. J Dairy Sci 96: 4242-4251. DOI: 10.3168/jds.2012-6511.

Li Y, Yu J, Goktepe I, Ahmedna M. 2016. The potential of papain and alcalase enzyme and process optimizations to reduce allergenic gliadins in wheat flour. Food Chem 196: 133881345. DOI: 10.1016/j.foodchem.2015.10.089.

Lopez-Solanilla E, Gonzalez-Zorn B, Novella S, Vazquez-Boland JA, Rodriguez-Palenzuela $P$. 2003. Susceptibility of Listeria monocyte-genes to antimicrobial peptidas. FEMS Microbiol Letter 226: 101-105.

Lopez-Exposito I, Quiros A, Amigo L, Recio I. 2007. Casein hydrolysate as a source of anti-microbial, antioxidant and antihypertensive peptides. Le Lait 87: 241-249. DOI: 10.1051/lait:2007019.

Lorenzon EN, Cespedes GF, Vicente EF, Nogueira LG, Bauab TM, Castro MS, Cilli EM. 2012. Effect of dimerization on the structure and biological activity of antibacterial peptida Ctx-Ha. Antimicrob Agents Ch 56: 3004-3010. DOI: 10.1128/AAC.06262-11.

Maurer HR. 2001. Bromelain: biochemistry, pharmacology and medical use. Cell Mol Life Sci 58: 1234-1245.

McCann KB, Shiell BJ, Michalski WP, Lee A, Wan J, Roginski H, Conventry MJ. 2006. Isolation and characterisation of antibacterial peptidas derived from the $f(164-207)$ region of bovine $\alpha_{\mathrm{S} 2}$-casein. Int Dairy J 16: 316-323. DOI: 10. 1016/j.idairyj.2005.05.005.

Mendoza F, Maqueda M, Galvez A, Martinez-Bueno M, Valdivia E. 1999. Antilisterial activity of peptide AS-48 and study of changes induced in the cell envelope properties of an AS-48 adapted strain of Listeria monocytogenes. Appl Environ Microbiol 65: 618-625.

Mihajlovic M, Lazaridis T. 2010. Antimicrobial peptides in toroidal and cylindrical pores. Biochim Biophys Acta 1798: 1485-1493. DOI: 10.1016/j. bbamem.2010.02.023.

Mondhe M, Chessher A, Goh S, Good I, Stach JEM. 2014. Species-selective killing of bacteria by 
antimicrobial peptida-PNAs. PLoS ONE 9: e89082. DOI: 10.1371/journal.pone.0089082.

Moslehishad M, Ehsani MR, Salami M, Mirdamadi S, Ezzatpanah, Naslaji AN, Moosavi-Movahedi AK. 2013. The comparative assessment of ACE-inhibitory and antioxidant of peptida fraction obtained from fermented camel and bovine milk by Lactobacillus rhamnosus PTCC 1637. Int Dairy J 29: 82-87. DOI: 10.1016/j. idairyj.2012.10.015.

Mundi S, Aluko RE. 2014. Inhibitory properties of kidney bean protein hydrolysate and its membrane fraction against renin, angiotensin converting enzyme, and free radicals. Austin $\mathrm{J}$ Nutr Food Sci 2: 1008.

Munoz MT, Caballer DB, Lizana MF,G Mendiola R, Montano PP, Cano MS. 2004. Selective allergy to sheep's and goat's milk proteins. Allergol Immunopat 32: 39-42. DOI: 10.1016/S03010546(04)79222-8.

Muro C, Riera F, Fernandez A. 2013. Advance in the fractionation of milk biopeptides by means of membrane processes. Intech 241-266. DOI: 10.5772/53674.

Nandhini B, Angayarkanni J, Palaniswamy M. 2012. Angiotensin converting enzyme inhibitor activity and antioxidant properties of goat milk hydrolysates. Int J Pharm Pharm Sci 4: 367370.

Nguyen LT, de Boer L, Zaat SAJ, Vogel HJ. 2011. Investigating the cationic side chains of the antimicrobial peptide tritrpticin: hydrogen bonding properties govern its membranedisruptive activities. BBA-Biomembranes 1808: 2297-2303. DOI: 10.1016/j.bbamem.2011.05. 015.

Picot L, Ravallec R, Fouchereau-Peron M, Vandanjon $L$, Jaouen $P$, Chaplain-Derouiniot $M$, Guerard F, Chabeaud A, LeGal Y, Alvarez OM, Berge J, Batista I, Pires C, Thorkelsson G, Delannoy C, Jakobsen G, Johansson I, Bourseau P. 2010. Impact of ultrafiltration and nanofiltration of an industrial fish protein hydrolysate on its bioactive properties. J Sci Food Agr 90: 1819-1826. DOI: 10.1002/jsfa. 4020.

Pownall TL, Udenigwe CC, Aluko RE. 2010. Amino acid composition and antioxidant properties of pea seed (Pisum sativum L.) enzymatic protein hydrolysate fractions. J Agr Food Chem 58: 4712-4718. DOI: 10.1021/jf904456r.

Prior RL, Wu X, Schaich K. 2005. Standardized methods for determination of antioxidant capacity and phenolics in foods and dietary supplements. J Agr Food Chem 53: 4290-4302. DOI: $10.1021 /$ jf0502698.
Rowan AD, Buttle DJ, Barrett AJ. 1990. The cysteine proteinases of the pineapple plant. Biochem J 266: 869-875.

Sabahelkheir MK, Fat en MM, Hassan AA. 2012. Amino acid composition of human and animal's milk (camel, cow, sheep and goat). ARPN J Sci Technol 2: 32-34.

Saha M, Debnath C, Pramanik AK. 2015. Listeria monocytogenes: An emerging food borne pathogen. Int J Curr Microbiol App Sci 4: 52-72.

Salampessy J, Phillips M, Seneweera S, Kailasapathy K. 2010. Release of antimicrobial peptides through bromelain hydrolysis of leatherjacket (Meuchenia sp.) insoluble proteins. Food Chem 120: 556-560. DOI: 10.1016/j.foodchem. 2009.10.054.

Szwajkowska M, Wolanciuk A, Barlowska J, Krol J, Zygmunt L. 2011. Bovine milk proteins as the source of bioactive peptidas influencing the consumers immune system. Anim Sci Pap Rep 29: 269-280.

Thaipong K, Boonprakob U, Crosby K, CisnerosZevallos L, Byrne DH. 2006. Comparison of ABTS, DPPH, FRAP, and ORAC assays for estimation antioxidant activity from guava fruit extracts. J Food Compos Anal 19: 669-676. DOI: 10.1016/j.jfca.2006.01.003.

Uckert S, Stief CG, Lietz B, Burmester M, Jonas U, Machtens SA. 2002. Possible role of bioactive peptides in the regulation of human detrusor smooth muscle-functional effects in vitro and immunohistochemical presence. World $\mathrm{J}$ Urol 20: 244-249.

Udenigwe CC, Aluko RE. 2011. Chemometric analysis of the amino acid requirement of antioxidant food protein hydrolysates. Int $\mathrm{J}$ Mol Sci 12: 3148-3161. DOI: 10.3390/ijms 12053 148.

Vandanjon $L$, Johannsson $R$, Derouiniot $M$, Bourseae, Jaouen P. 2007. Concentration and purification of blue whiting peptida hydrolysate by membrane processes. J Food Eng 83: 581-589. DOI: 10.1016/j.jfoodeng.2007.03. 040.

Yin LM, Edward MA, Li J, Yip CM, Deber CM. 2012. Roles of hydrophobicity and charge distri-bution of cationic antimicrobial peptides in peptidesmembrane interaction. J Biol Chem 287: 77387745. DOI: 10.1074/jbc.M111. 303602.

Zhao LJ, Huang YB, Gao S, Cui Y, He D, Wang L, Chen YX 2013. Comparison on effect of hydrophobicity on the antibacterial and antifungal activities of $\alpha$-helical antimicrobial peptides. Sci China Chem 56: 1307-1314. DOI: 10.1007/s11426-013-4884-y. 